\title{
9
}

\section{The Politics and Practicalities of Designing Australia's Force Structure}

\author{
Peter Jennings
}

In the cover letter to his 1986 Review of Australia's Defence Capabilities, ${ }^{1}$ Paul Dibb set out for then Defence Minister Kim Beazley the key challenges for his study:

The Review could obtain no material centrally endorsed by the higher Defence structure which explained, for example, the strategic rationale for a 12-destroyer Navy, three fighter squadrons, six Regular Army battalions and an Army Reserve target of 30,000. Few of the documents made available to the Review examine, in any rigorous, analytical way, the size of forces we should have for credible contingencies and as a contribution to the expansion base. Most focus on justifying the present force structure rather than estimating what our strategic circumstances require. The key difficulty here is that the Department and the ADF do not agree on the appropriate level of conflict against which we should structure the Defence Force.

It has almost been 30 years since these words were written. Arguably Australian defence policy still suffers from the first of Dibb's identified problems: an inadequate way of framing the strategic rationale behind

1 Paul Dibb, Review of Australia's Defence Capabilities, report to the Minister for Defence (Canberra: Australian Government Publishing Service, 1986). 
capability acquisitions. In 2016 we might ask what the rationale is for a 12-submarine navy, or an air force with 100 fighter aircraft and an army with three regular brigades. In fact, the shape of the Australian Defence Force (ADF) remains similar to that of the mid-1980s, albeit with more capability based on significant technological advances. By contrast, the modern Australian Defence Organisation seems largely to have overcome - or at least hides more effectively — deep conceptual divisions over key force-structuring concepts.

Have Australia's defence policymakers got better at designing the conceptual basis for force-structure decisions? To answer that question, it is necessary to understand how defence policymaking interacts with politics. It must be remembered that the locus of defence decisionmaking resides around the Cabinet room and ministerial suites in Parliament House, not at the Defence headquarters at Russell, which is just a few kilometres away. This chapter argues that Dibb's 1986 review set the model for how political decision-making intersects with defence force development thinking. Some important benefits flowed from continuing the 'Dibb model', including achieving relatively high levels of political bipartisanship around force-structure decisions and establishing a cross-party consensus on the importance of the US alliance. As governments have articulated their evolving strategic orientations for defence it seems almost incidental that the structure of the ADF remains remarkably unchanging. Looking to the future we need to ask if Dibb's approach to taking force-structure options to government will continue to shape how Australian policymaking is done.

\section{The Theatre of Defence White Papers}

A curious artefact of Australian defence policymaking is the attention lavished on Defence white papers. While other countries may write these policy statements more often (Japan has an annual white paper), none vest in them such talismanic power as Australia. Since the end of the Vietnam War, Australian governments have prepared a white paper in 1976, 1987, 1994, 2000, 2009, 2013 and 2016. Each is more elaborate in terms of the effort invested in developing them and the political and public attention devoted to their release. In the case of the last four white papers, it took large teams more than 12 months' 
work to develop policy material for government. In 2000 and 2009 a deputy secretary worked full time on policy work. In those years, and in 2015-2016, extensive public consultation processes were established to support the white paper; many Cabinet submissions were prepared to help steer policy direction; and extensive supporting work was done internally to inform force-structure design, estate, science, industry, personnel and equipment costing.

There is no doubt that politics plays a critical role in motivating governments and oppositions of the day to commit to develop these documents. ${ }^{2}$ The 2000 White Paper was prompted by the need for the government under John Howard to be seen to respond to the strategic shock of East Timor's violent transition to independence from Indonesian sovereignty. The 2009, 2013 and 2016 white papers were all initiated by pledges to deliver these policy statements either after an election or just before one.

It is hardly surprising in a competitive and open electoral system that political parties would want to use policy statements to seek partisan political advantage, even though this advantage is often pursued through a veil of pledges of bipartisanship on national security. Defence white papers have become the principal vehicle for Australian governments to align their political interests with a credible strategic plan for the country's defence. A successfully concluded white paper confers a degree of credibility on a government and a hoped-for public view that the government in question is strong on national security. White papers create the opportunity to address challenging and divisive policy issues.

Given their political value, Defence white papers will always have a measure of theatre about them - the 2009 document, for example, was launched from the deck of a warship in Sydney Harbour and the 2013 statement was released at the Royal Australian Air Force (RAAF) Base Fairbairn in Canberra, with an array of military equipment flown in to act as background props. So intense has the focus become on the development and release of these documents that one wonders if white papers are not at risk, like the largest of the dinosaurs, of sinking into the mire under their own ponderous weight. But one should not

2 I chart the intersection of politics and policy in Defence white papers up to 2013 in 'The Politics of Defence White Papers', Security Challenges, Vol. 9, No. 2 (2013), pp. 1-14. 
underestimate the seriousness of the policy intent in these documents. Given the scale and duration of the military-capability investments involved, as well as the seriousness of the strategic challenges at issue, white papers will likely persist as key vehicles driving the politics and policy of Australia's defence.

\section{A Critical Precursor to the Review of Defence Capabilities}

At 58 pages, the 1976 White Paper is the shortest of the seven Defence statements since that time, and the one with the clearest authorial voice - that of the formidable Secretary of Defence, Sir Arthur Tange. Almost 40 years after it was released, the 1976 Defence White Paper remarkably echoes many of today's defence and security preoccupations. For example, it uses the term 'IndoPacific' to describe Australia's broad strategic canvas, within which South-East Asia and the south-west Pacific are 'areas of Australia's primary strategic concern'. The paper worries about prospects for the Australia-Indonesia relationship, noting that it has 'successfully weathered occasional sharp differences'. ${ }^{3}$ Critically, the document sets out the beginnings of the idea of 'self-reliance' in defence planning in the context of Australia's close alliance with the United States.

On force structure, Tange's document would not require much editing to pass muster as a description of the current status. It puts a premium on maritime capabilities for intelligence, surveillance and reconnaissance, proposes to expand the size of the surface fleet 'preferably for construction in Australia' and has a helpfully clear and direct statement on the role of submarines:

Submarines are a potent deterrent with important functions in anti-shipping and anti-submarine warfare, covert reconnaissance/ surveillance and patrol, clandestine operations, and mine warfare.

On land forces, the focus is on deployability and sustainability over long distances using a divisional structure as recognisable today as it was on the Western Front in 1918. The biggest structural difference

3 Commonwealth of Australia, Australian Defence, presented to Parliament by the Minister for Defence the Hon. D.J. Killen (Canberra: Australian Government Publishing Service, Nov. 1976). 
between the ADF of 1976 and 2016 is the contemporary absence of carrier-borne fixed-wing aircraft. The 1976 document foreshadows that this capability was in decline - it was phased out half a decade later. A briefly revived interest in the short take-off and vertical landing (STOVL) version of the F-35B in 2014 and 2015 shows how doggedly force-structure ideas persist. ${ }^{4}$

For all of its intellectual promise, the 1976 Defence White Paper failed - as quite a number have - because of a lack of follow-through on budget and force-structure implementation. In the aftermath of the Vietnam conflict, defence spending levels declined. The then Prime Minister Malcolm Fraser had a prickly relationship with the military based on his unhappy experiences as Defence Minister in John Gorton's government at the end of the 1960s. Tange criticised Fraser for his 'overly distrustful' and unreasonable demands on the department, which was not well equipped to meet Fraser's requests for short-notice briefing material. The Defence Department, Sir Arthur observed, 'had, with few outstanding exceptions, a mediocre intellectual level in 1969 when Fraser became minister' ${ }^{5}$ Fraser's own Minister for Defence, Jim Killen, was held in great affection by many but was not regarded as a strong driver of departmental policy. As such the policy plans articulated in the 1976 White Paper languished for want of a sponsor.

\section{Defence Dysfunction: Dibb Does his Duty}

When Labor was elected to office in 1983, Prime Minister Bob Hawke faced a series of dilemmas on defence and national security policy. His predecessor as leader of the Australian Labor Party in opposition, Bill Hayden, had taken the party to the left on nuclear and US-alliance issues. Anti-nuclear support in Australia was growing at the same time as Hawke faced pressure from the United States to support testing of the MX missile. Vocal campaigns against Australia-US joint facilities and the visits of potentially nuclear-armed warships were generating

4 Richard Brabin-Smith \& Benjamin Schreer, 'Jump Jets for the ADF?', ASPI Strategic Insights, No. 78 (Barton: Australian Strategic Policy Institute, 17 Nov. 2014).

5 Sir Arthur Tange, quoted from an interview with Philip Ayres, Malcolm Fraser: A Biography (Melbourne: William Heinemann Australia, 1987), p. 163. 
popular support. In New Zealand, David Lange was articulating an unambiguously anti-nuclear policy that saw trilateral Australia-New Zealand-United States (ANZUS) cooperation suspended in $1984 .^{6}$

Hawke's challenge was to set out an approach to the US alliance, the joint facilities and Australian defence policy more broadly that could become the basis of Labor policy. Against this difficult background, the government directed Defence to develop a full-scale review of Australia's defence policy options. The Secretary of Defence at the time was Sir William 'Bill' Cole. Writing a few years after these events, Cole reflected on the experience:

For well over a year, the Department, under successive Secretaries, and ADF Headquarters, under Successive Chiefs of the Defence Force, made absolutely no progress with that review - to which all concerned knew Government attached great importance - because the various protagonists could not agree on how the review should be approached. Let alone not getting the task finished, despite considerable efforts, Defence could not get it started. ${ }^{7}$

Cole added rather archly in a footnote: 'If the issue here was which of the contending parties was responsible for the stalemate or what the Minister should have done, I would have more to say.' The lack of communication between the ADF and defence civilians became legendary. Dibb's 1985 appointment by the newly promoted Defence Minister, Kim Beazley, to conduct the review of Australia's defence capabilities was the government's solution to break this impasse.

It's always the case that well-designed processes give rise to better policy outcomes. The processes put in place for the Dibb Review directly contributed to what was a successful Defence White Paper for Labor in 1987. First, Dibb was given powerful and unambiguous terms of reference, most particularly to review 'the content, priorities and rationale of defence forward planning in the light of the strategic and financial planning guidance endorsed by the Government', and 'to advise on present and future force capabilities'. ${ }^{8}$ In effect there was no hiding from the government's intent as to what it wanted.

6 Bob Hawke, The Hawke Memoirs (Melbourne: William Heinemann Australia, 1994), p. 228.

7 Bill Cole, 'A New Approach to Defence: The Wrigley Report and After', Australian Institute for Public Policy (AIPP) Policy Paper, No. 19 (1990), p. 24.

8 Dibb, Review of Australia's Defence Capabilities (1986), p. xv. 
A second process strength was that Dibb was to report directly to Beazley, so Defence was unable to filter his advice. Third, Dibb's report was to reflect his views only, it was not to be a statement of government policy or departmental preference. This produced a fourth process advantage, which was that the government gave itself an option not to follow all of Dibb's recommendations. On tabling the report, Beazley told parliament: 'The Dibb review will now become a basic input to the development of a government white paper on Defence policy. ${ }^{\prime}$ The government could, and indeed did, change elements of Dibb's recommendations to take account of some of the critiques of the review.

Dibb's proposed force structure was built around what he called a 'strategy of denial', a layered defensive concept that put a premium on air and maritime capabilities protecting the approaches to Australia, and an Army primarily designed around vehicle-mounted infantry able to respond to low-level and 'escalated low-level' contingencies on Australian territory. Dibb's focus was strongly based on strategic geography and the assessment that 'the archipelago to our north is the area from or through which a military threat to Australia could most easily be posed. ${ }^{10}$ While the review's focus was on force structure, not regional security, a good deal of Dibb's capability proposals flowed from that single sentence.

One of the most difficult issues tackled in the review was to set an appropriate balance between the low likelihood of high-intensity conflict against a Service interest to sustain forces able to operate in the most demanding combat scenarios. Dibb concluded Defence should 'emphasise the weight to be given to credible contingencies - but not at as low a level as the department supports'. The report set out the benefits of the US alliance but stressed 'there is no requirement for Australia to become involved in United States contingency planning for global war'.

The critique of the review began in earnest even as Beazley tabled it in parliament. The leader of the Opposition, Andrew Peacock, snapped at Beazley: 'It is a policy of retreat — right into a shell'. To which the

9 Kim Beazley, 'Ministerial Statement: Review of Australia's Defence Capabilities', House of Representatives Hansard, 3 Jun. 1986.

10 Dibb, Review of Australia's Defence Capabilities (1986), p. 4. 
Minister replied: 'It is a shell which covers 25 per cent of the entire globe.' (Watching the show from the House of Representatives visitors' gallery helped inspire me into a Defence career.) Ian Sinclair, then leader of the National Party and Shadow Minister for Defence, cannily positioned the Coalition voice for the debate. He agreed with some equipment proposals, moving an Army presence to Darwin and also supported creating a Vice Chief of the Defence Force (VCDF) to boost more joint capability development across the Services. But Sinclair worried that the Association of Southeast Asian Nations (ASEAN) would see the report as 'isolationist', that it did not encompass the 'wider role' Australia should play in the US alliance and was concerned that the report could be seen as 'restricting Australia's defence capability, not expanding it'. ${ }^{11}$

Media commentary on the review was extensive and broadly favourable - remarkably all the major newspapers editorialised on it, something very unlikely to occur today. Tange, then approaching 72 years of age, wrote for the Age:

It is inconceivable that the services, or the outside critics of the bureaucracy, would tolerate a senior departmental officer drafting a report on military capabilities for the minister. Dibb was presumably accepted because of his abundant abilities, and because he was no precedent for the future. ${ }^{12}$

In fact the review set a precedent, followed many times by subsequent governments, for ministers to appoint external advisers to review defence functions.

The 1987 Defence White Paper (actually titled a 'Policy Information Paper') made some subtle changes of emphasis - promoting a 'defence self-reliance' concept rather than Dibb's strategy of denial. The White Paper placed significantly more emphasis on regional engagement.

11 Ian Sinclair, 'Speech in Reply to the Ministerial Statement', House of Representatives Hansard, 3 Jun. 1986.

12 Sir Arthur Tange, 'The Dibb Report: After the Excitement of Heroes and Villains ...', Age, 5 Jun. 1986. Press clippings on the review were collected by the Current Information Service of the Department of the Parliamentary Library, 'Editorials and Selected Press Comment on the Dibb Report', 10 Jun. 1986. This compilation includes a biographical piece on Dibb by John Moses, writing in the Australian of 4 June 1986. Titled 'Bright light in the bureaucratic murk', Moses writes: 'Paul Dibb has been now, for more than 10 years in Australia, a quiet but formidable strategist and intelligence expert. The kind of person who might appear in a BBC television series (but not as principal actor) about the hidden world of global information gathering.' 
On South-East Asia, for example, Dibb stressed the importance of Indonesia but said that '[i]n defence terms, other ASEAN states do not have the geographical proximity to involve our military interests so closely. The Five Power Defence Arrangements (FPDA), including our presence at Butterworth, reflect the concerns of a previous era.' By contrast the White Paper stressed that FPDA 'formalised' Australia's 'regional responsibilities' and anticipated 'scope for increased emphasis on logistic arrangements in regional military cooperation' with the FPDA countries. There was also a strong statement of Australian obligations to the security of Papua New Guinea, which was not mentioned in the public Dibb review. ${ }^{13}$

The Hawke Government used the 1987 Defence White Paper to address a US concern that it was tending to be too isolationist. Hawke observed in his memoirs: 'Dibb addressed only the issue of capabilities. Then in 1987, in the Defence White Paper, the government configured the self-reliance concept with our alliance arrangements. ${ }^{14}$ It's important to remember that the tenor of the times was shaped by New Zealand's defection from ANZUS. In September of 1986 - that is after the Dibb Review's publication but before the 1987 Defence White Paper - the United States suspended its ANZUS-treaty obligations towards New Zealand over Wellington's anti-nuclear policy. Beazley noted: 'Basically the Americans were not worried about the New Zealanders. They were worried about us ...' ${ }^{\prime 5}$ The White Paper set out to remove any possible basis for US concern about its alliance with Australia.

As a policy exercise, the combination of the Dibb Review and the 1987 White Paper met a number of important objectives. It helped Labor establish a basis for its continued support of the US alliance - something that was critically important in electoral terms, given the strong public attachment to the relationship. For the Liberal and National coalition the reviews helped to crystallise their own approach to defence policy, by stressing a more outward-looking, expeditionary

13 Dibb, Review of Australia's Defence Capabilities (1986). The ASEAN and PNG references are at p. 48 (Commonwealth of Australia, The Defence of Australia 1987: A Policy Information Paper (Canberra: Australia Government Publishing Service, 1987)). References to FPDA and PNG are on pp. 6-7.

14 Hawke, The Hawke Memoirs (1994), p. 229.

15 Kim Beazley, quoted in a discussion on the New Zealand relationship, Parliament of the Commonwealth of Australia, ANZUS After 45 Years: Seminar Proceedings 11-12 August 1997, Joint Standing Committee on Foreign Affairs, Defence and Trade, House of Representatives, Canberra, 1997, p. 56. 
bias for the ADF. This contrasted with Labor's more constrained approach to using the ADF based on geography. These were important shades of difference, but still enabled the parties to claim that large parts of defence policy had bipartisan support.

The 1986 and 1987 statements established an enduring set of criteria for evaluating force-structure proposals. The statements broke an impasse in Defence preventing proper joint-capability development. Elements of this approach have been used by subsequent governments in defence policy development right up to the 2016 White Paper. Regrettably, the 1987 policy set another pattern for subsequent white papers: its release was quickly followed by a reduction in the growth of defence spending. To date only the 2000 White Paper has not followed this trend and it remains to be seen once the 2016 statement is issued if there will continue to be bipartisan support to lift defence spending to 2 per cent of GDP.

\section{The 1990s and a Strong Australia}

The politics of defence force structure development has remained remarkably consistent in the quarter of a century that has followed Dibb and Beazley's work, but Australian policy settings have changed in reaction to the shifting global and Asia-Pacific strategic outlook. Three broad strategic changes in particular led to a dramatic increase in the use of the ADF: first, the end of the Cold War unlocked a frozen strategic balance in the Middle East, giving rise to the first cycle of Gulf Wars, the Soviet invasion of Afghanistan and the rise of Islamist extremism, which ultimately led to the 11 September 2001 Al-Qaeda attacks in the United States.

Closer to home, the second strategic change was the marked decline of political and social stability in Indonesia, East Timor and the Pacific Island states. Indonesia's difficult transition from a kleptocratic dictatorship to an at times uncertain democracy gave rise to Australia's East Timor intervention in 1999 and, separately, to a substantial threat from homegrown Islamist terrorism. In the Pacific Islands, internal instability fuelled by crumbling social structures, political incompetence and economic stagnation provided the fuel for a series of violent eruptions forcing Australia to lead costly Defence and police stabilisation missions. In contrast to the 1980s and most of the 
1990s, from 1998 until the present the ADF has been on continuous operations, at times simultaneously in two or more areas. The surprise is that this has had such minimal impact on ADF force-structure design.

The third strategic change was the rapidly emerging growth of Asia, fuelling expanding military capabilities. China's economic reform juggernaut started with Deng Xiaoping's reforms in December 1978. From a slightly earlier start, a number of South-East Asian countries were emerging as the 'Tiger economies' and enjoying rapid growth. Australia was increasingly engaging the region in trade and investment and the case for deepening military engagement was becoming stronger. While the core element of Australian Defence white papers focused on long-term military capability development, there was also a need to address defence posture - that is how the current force engaged with regional counterparts. Shaping the behaviour of key countries in ways that promoted Australian interests could make an important peacetime contribution to stability.

The curse of policy statements is that they start to date as soon as they are released and governments are forced to decide how long to stick with a policy line or to make a break with the past and accept the inevitability of strategic change. Labor's Defending Australia: Defence White Paper 1994 reflected an awkward compromise between continuity and change, in particular how far to acknowledge that the end of the Cold War and the fall of the Berlin Wall was recasting Australia's broader strategic outlook. Tabling the White Paper in parliament, then Prime Minister Paul Keating hinted at the underlying challenge:

Some commentators have seen a tension in the two objectives of defence self-reliance and greater strategic engagement with the countries around us, but I believe no such tension exists. In defence policy no less than in other areas of Australia's engagement with Asia, our efforts to improve our own capacities as a nation and our ability to operate successfully in the region are two sides of the same coin. ${ }^{16}$

16 Prime Minister Paul Keating, 'Ministerial Statement: Defending Australia: Defence White Paper 1994', House of Representatives Hansard, 8 Dec. 1994. 
In his brief tenure as Leader of the Opposition, Alexander Downer replied that the 1987 White Paper was 'outdated and superseded' and that the 1994 statement 'comes several years too late':

May I refer the government to ... the Coalition's 1992 defence policy, A Strong Australia. Those opposite will find there a rational and detailed blueprint for what we called then 'a policy of cooperative regional defence'. No doubt those who wrote the white paper are well acquainted with those pages, because the ideas in them have been extensively adopted. ${ }^{17}$

A Strong Australia (a document that I was closely involved in writing) sought to differentiate the Coalition's defence offering by promoting a stepped-up policy of practical military-to-military cooperation in the Asia-Pacific. It argued:

central to Australia's own security is the security of the immediate region. It is almost axiomatic that a direct threat to territorial Australia will only emerge if there is initially a collapse in the region's security environment. Australian defence planning should, therefore, be at least partially directed towards enhancing the security of the region. ${ }^{18}$

The Coalition lost the 1993 election and so never had the opportunity to implement A Strong Australia. Three more years of Opposition saw the Coalition continuing to chew on the issue of how to articulate a defence policy setting that wasn't constrained to a narrow approach to the Defence of Australia (DOA). In part this was about product differentiation — seeking a convincing political explanation for a different approach - but just as important was an emerging view that strategic changes were forcing Australia to take a more outwardlooking approach to defence. Australia's Defence, the Coalition's defence policy statement issued in February 1996 a few weeks before the March election, set out a sharply different approach to that of the 1987 White Paper:

The Coalition believes that the best way to ensure the security of Australia is to maintain a capable Defence Force and to take actions that support a favourable strategic environment in Southeast and

17 Alexander Downer, Leader of the Opposition, 'Ministerial Statement: Defending Australia: Defence White Paper 1994', House of Representatives Hansard, 8 Dec. 1994.

18 The Coalition, A Strong Australia: Rebuilding Australia's Defence: Defence Policy of the Federal Liberal Party/National Party Coalition (Oct. 1992), p. 25. 
Northeast Asia and the South Pacific. Close military, economic and political ties with the region are an effective way of providing for Australia's security. ${ }^{19}$

In its discussion of ADF capabilities, the policy statement prudently said it would wait for Defence advice before being too prescriptive about future acquisitions, but the document set out some guiding priorities, which included:

- Capacity for control and surveillance of the sea-air gap ...

- And the capacity to undertake strategic strike against an adversaries' operational and support infrastructure and to interdict proximate sea lanes of communication. ${ }^{20}$

In effect, this was taking DOA into the archipelago to Australia's north. The flurry of election campaigning often means that pre-polling day policy announcements are ignored, as was Australia's Defence. But in its focus on the wider Asia-Pacific and with a forward interpretation of DOA, the document articulated a distinct Coalition approach to defence.

In his speeches as the first Defence Minister in the Howard Government, Ian McLachlan searched for the right language to capture the Coalition approach. $^{21}$ In a May 1996 speech delivered at The Australian National University's Strategic and Defence Studies Centre (SDSC), McLachlan said:

Our key defence policy aim is to develop military forces able to defeat any attack against Australia. No country has the interest or capacity to launch a full-scale invasion against Australia, so our focus is on countering more realistic levels of threat. Our purpose is to deter any potential aggressor and, if deterrence fails, to defeat the enemy in the sea and air approaches and on land.

That objective is, and must be, the core business of the ADF. Additionally, the government will make an effective contribution to regional security. Australia's defence does not begin at the coast-line.

19 John Howard, Leader of the Opposition, Australia's Defence, 13 Feb. 1996, p. 14, s. 4.1.

20 Howard, Australia's Defence, p. 15, s. 5.5.

21 In the interests of full disclosure I should note that I was Ian McLachlan's chief of staff during his time as Defence Minister and soon took on the role of being his speechwriter. 
On the contrary, Australia cannot be secure if the region is unstable. Defence is making a growing contribution to Australia's wider regional security aims.

One of the issues we need to examine is how far that particular role can and should be taken. Australia cannot be adequately defended only by guarding its territory and by merely looking on at the changes sweeping through Asia [emphasis added]. ${ }^{22}$

The combination of product differentiation and strategic change crystallised in the December 1997 publication of Australia's Strategic Policy, ${ }^{23}$ the unclassified version of a strategic assessment undertaken by Defence at McLachlan's direction. Tabling the document in parliament, McLachlan said:

The focus of our policy remains on our ability to defend Australia. Australia's strategic interests do not begin and end at our shoreline. It would be a serious mistake to think we could adopt a 'fortress Australia' strategy in the event of a deterioration of regional stability. We cannot be secure in an insecure region.

... We can no longer assume that forces able to meet low-level contingencies in the defence of Australia will be sufficient to handle conflict beyond our territory ...

The government, therefore, rejects the argument that we must choose between a Defence Force to defend Australia and one able within realistic limitations to operate overseas. The Defence Force must be able to do both. The issue Australia faces is how to build a Defence force able to ensure the security of the country and able to contribute to the security of our region. ${ }^{24}$

Australia's Strategic Policy was almost as blunt as the 1996 pre-election statement. The word 'proactive' was used as a slightly more benign formulation than 'pre-empt', but the military meaning was clear:

More proactive operations offer the opportunity to seize the initiative, impose real pressure on an adversary to stop attacking Australia, and

22 Ian McLachlan, 'Australian Defence Policy after the Year 2000', in Helen Hookey \& Denny Roy (eds), Australian Defence Planning: Five Views from Policy Makers (Canberra: Strategic and Defence Studies Centre, 1997).

23 Commonwealth of Australia, Australia's Strategic Policy (Canberra: Department of Defence, 1997).

24 Ian McLachlan, 'Ministerial Statement: Australia's Strategic Policy', House of Representatives Hansard, 2 Dec. 1997. 
provide better confidence that Australian lives and property would be protected. That is not to suggest we would contemplate attacking the population centres of an aggressor. Rather, we would attack or threaten to attack - military assets and installations which could be used to attack Australia. ${ }^{25}$

Language as blunt as this about the potential use of offensive military capability wasn't seen again until the 2009 White Paper. The media reception was mixed, the Australian's headline following the release of Australia's Strategic Policy was: 'McLachlan's defence force gears up for war offshore. ${ }^{26}$ Many commentators saw the policy as presenting a return to the 'forward defence' strategy of the 1960s. That critique was vigorously resisted by McLachlan on the basis that a critical change was the increasing military capabilities of countries in the Asia-Pacific.

Much of the political debate on defence in the 1990s and early 2000s was around just how far forward into the region should the 1986 DOA be allowed to extend. It was useful for commentators and others to play up somewhat the apparent differences between a supposed Labor disposition for a 'fortress Australia strategy' and a Coalition preference for 'forward defence'. In reality there is less to the debate than at first meets the eye. DOA and 'forward defence' meet at some point in the archipelago of islands to Australia's north and further into SouthEast Asia. Elsewhere I have referred to this as 'DOA plus', which is where, to the surprise of many, Australia found itself in 1999 when it deployed a large stabilisation force into East Timor. ${ }^{27}$

The extension of the DOA concept further into the region reflected not so much a change of Australian thinking as it did a deterioration of regional stability that forced an Australian response. It pointed to the need to rethink Defence's capacity to deploy and sustain joint forces at significant distances from Australia. Given Australia's geographic position, it became clear as a result of the East Timor deployment that the requirements for an effective 'DOA plus' policy are practically identical to what is needed to sustain an expeditionary force.

25 Commonwealth of Australia, Australia's Strategic Policy (1997), p. 46.

26 Don Greenlees, 'McLachlan's Defence Force Gears up for War Offshore', Australian, 3 Dec. 1997, p. 1.

27 Peter Jennings, 'The Politics of Defence White Papers', Security Challenges, Vol. 9, No. 2 (2013), pp. 1-14. 
Writing in anticipation of the 2000 White Paper, Dibb made the following comment:

there can be no doubt that we do need to transform the ADF into a different sort of defence force to meet the strategic challenges of the 21st century. My view is that the defence of Australia and the archipelago to our north and east are now one force structure planning problem. This is what I have termed 'the regional defence of Australia' ${ }^{28}$

What seemed a relatively novel proposition in 1996 and 1997 became the new orthodoxy in 2000. The seismic shift in strategic thinking was, of course, prompted by the 1999 East Timor crisis.

\section{0 and the Timor Shock}

Howard and McLachlan wisely held off producing a Defence white paper in the government's first term, ${ }^{29}$ but the experience of mounting Australia's largest military operation since the Vietnam War - the International Force in East Timor (INTERFET) — profoundly shaped Howard's thinking on defence. He wrote in his autobiography:

I realised that for a long time into the future Australia would need to spend a lot of money on Defence. We had mounted a hugely successful operation, but launching and sustaining it had put an enormous strain on our military resources, particularly our ground forces and strategic lift assets. ${ }^{30}$

The White Paper Defence 2000: Our Future Defence Force, set out a strategy for extending Australia's strategic interests more deeply into the Asia-Pacific region and equipping the ADF in ways that would support long-term stabilisation operations. The paper presented these objectives as an evolution of policy-thinking from the 1987 White Paper. It stated that 'the two highest tasks' for the ADF were:

28 Paul Dibb, 'Transforming the ADF's Force Structure For the 21st Century', Australian Defence Force Journal, No. 123 (Jul.-Aug. 2000), pp. 27-28.

29 This was notwithstanding my best efforts as McLachlan's chief of staff to have a white paper initiated. Howard was sceptical about the value of over-elaborate policy statements and McLachlan had a sense of the challenge that might be involved in getting Defence to develop one. McLachlan's view was that the business needed to be restructured first, which led him to initiate the Defence Efficiency Review.

30 John Howard, Lazarus Rising: A Personal and Political Autobiography (Sydney: Harper Collins, 2010), p. 357. 
First, Australia will maintain maritime capabilities - mostly air and naval forces - that can defend Australia by denying our air and sea approaches to any credible hostile forces. Second, Australia will maintain land forces - including the air and naval assets needed to deploy and protect them - that can operate as part of a joint force to control the approaches to Australia and respond effectively to any armed incursion onto Australian soil. Both those sets of capabilities would also be able to support the security of our immediate neighbourhood and contribute to coalition operations. ${ }^{31}$

Notwithstanding the reference to operations on Australian soil, there is no doubt that the government's thinking was focused on what was needed to deploy forces offshore. Howard said the Timor experience 'never left me' and directly led to subsequent decisions to purchase additional C-17 lift capability and to expand the size of the Regular Army. ${ }^{32}$

A clear strength of the 2000 White Paper was the decision to establish a rolling 10-year defence-capability investment plan and to 'commit' - as far as any government can tie future administrations - to a decade-long funding profile. The paper also sought to set out a clear strategic basis for key defence capabilities. The structure of the Army was to build around sustaining a brigade on operations for extended periods with an additional augmented battalion group able to perform a simultaneous separate operation. Air combat forces were to be 'at least comparable qualitatively to any in the region' and maritime forces were 'to maintain an assured capability to detect and attack any major surface ships, and to impose substantial constraints on hostile submarine operations, in our extended maritime approaches' ${ }^{33}$

The basic structure of the ADF as set out in the 2000 White Paper, right down to the numbers of key platforms, remained remarkably similar to that assessed by Dibb 15 years earlier. That said, the hard realities of Timor and following operations shifted the ADF's capabilities into more joint, better supported and more integrated capabilities. It may be true that there was no better articulated strategic grounds in 2000 than there had been in 1986 to explain why the RAAF had approximately

31 Commonwealth of Australia, Defence 2000: Our Future Defence Force (Canberra: Department of Defence, 2000), p. xii.

32 Howard, Lazarus Rising, 2000, p. 358.

33 Commonwealth of Australia, Defence 2000, 2000, p. xiii. 
100 combat aircraft. But at least by the time a squadron of F/A-18s were deployed to the Middle East in 2003, this was a capability more ready to fight in higher level contingencies. The elements of Defence that were deployed and used in the decade after 2000 got sufficient investment to make them more operationally effective. Force elements that were not called on - anti-submarine warfare (ASW), for example - tended to atrophy. This points to two important principles of force structuring: first, what gets used gets funded; and, second, operations lends more rigour to capability decision-making.

Was Defence any better placed to develop the 2000 White Paper than Dibb found the organisation to be in 1986? The answer is clearly 'yes' because the 2000 statement was produced by the department, albeit by a team lead by Hugh White that removed itself from Russell to what is now the location of the Australian Strategic Policy Institute (ASPI) in Barton, Canberra. Like Dibb, White brought a focus to the task that wasn't to be diverted by departmental bickering. As an experienced prime minister by 2000, Howard knew what he wanted of Defence so he gave the White Paper the same purposeful momentum that Beazley provided 15 years earlier. The Timor experience created a Defence organisation with less time for internal gamesmanship. The senior leaders of the ADF were genuinely thinking of the entity more as 'the $\mathrm{ADF}^{\prime}$ rather than a loose coalition of Services. Moreover, there was a broad (but never universal) agreement between the ADF and the civilian elements of Defence that supported the White Paper's outcomes.

Politically the Coalition Government benefited from encouraging a perception that it was strong on national security and better able than Labor to handle defence. In January 2001, the Newspoll organisation added defence to the list of policy areas over which it asked Australians which political party was the better manager. For that poll, 40 per cent nominated the Liberal/National Coalition and 23 per cent Labor. ${ }^{34}$ The Coalition retained a similar lead as the party 'best able to handle defence' for the life of the Howard Government.

34 Newspoll findings for January 2001 are available at polling.newspoll.com.au/image_ uploads/cgi-lib.12728.1.1002issues.pdf (accessed 2 Sep. 2015). It is possible to search the Newspoll archives on defence and national security polling results at www.theaustralian.com. $\mathrm{au} /$ national-affairs/newspoll. 


\section{Yet More White Papers: 2009 and 2013}

The 2009 White Paper, Defending Australia in the Asia-Pacific Century: Force 2030, was Labor's first white paper since 1994. For Prime Minister Kevin Rudd, a former diplomat with a hard-edged strategic world view, the statement gave the opportunity to make his own definitive mark on defence policy. A key challenge was to differentiate the product from the Howard Government's claim to be the 'natural party' of national security. The White Paper started with a list of priorities, the first of which might have been lifted from its 1987 predecessor: 'Australia's most basic strategic interest remains the defence of Australia against direct armed attack.' But with this respect paid, it rapidly became clear that the statement was far more outward looking:

The more Australia aspires to have greater strategic influence beyond our immediate neighbourhood - that is to say the ability to exert policy influence that is underpinned by military power - the greater the level of spending on defence we need to be prepared to undertake. ${ }^{35}$

The ability to 'exert policy influence' went at least as far as ensuring 'that no major military power ... could challenge our control of the air and sea approaches to Australia, [or have] access to bases in our neighbourhood from which to project force against us'. This approach called for a 'more potent force', which lead to the key policy announcement in the White Paper:

The major new direction that has emerged through consideration of current and future requirements is a significant focus on enhancing our maritime capabilities. By the mid-2030s, we will have a more potent and heavier maritime force. ${ }^{36}$

If this amounted to a variation of DOA, it was DOA on steroids 'DOA plus, plus' perhaps. The centrepiece of the maritime program was to double the submarine fleet from six to 12 boats, with the new class of submarine planned to 'have greater range, longer endurance on patrol, and expanded capabilities compared to the current Collinsclass submarine'.

35 Commonwealth of Australia, Defending Australia in the Twentieth Century: Force 2030 (Canberra: Australian Government Publishing Service, 2009), p. 11.

36 Commonwealth of Australia, Defending Australia (2009), p. 13. 
The grand conceptions of the 2009 White Paper were undermined by the leadership turmoil and administrative chaos of the Rudd Government and by the impact of the global financial crisis which started to bite hard as the document was being finalised. This forced a rather sad late inclusion as the second paragraph in the Executive Summary of the statement:

The global economic crisis is the most fundamental economic challenge facing this Government. At times such as these, the Government must be fiscally responsible. It would be reckless to commit substantial new resources to Defence while uncertainty surrounding the crisis remains. ${ }^{37}$

In essence the policy was dead in the water before it went to the printers. Looking back on the experience a few years later, then Foreign Minister Bob Carr reported on a discussion with the White Paper's principal author, Michael Pezzullo:

He said, 'take the 2009 Defence White paper. That was a case of over-hedging'. By this he meant the controversial chapter talking up Chinese strategic assertiveness and the prospects of major power conflict ... but the 2013 Defence white paper which pulled back a bit (but not in respect of its commitment to those defence acquisitions), that would be an example of plain hedging. ${ }^{38}$

The Defence White Paper 2013 was a curious policy in terms both of content and timing. ${ }^{39}$ As Carr observed, it reasserted the 2009 Rudd force structure but without a convincing funding base. The release of the White Paper just a few months before the 2013 October election suggested that it was there as a place marker rather than a believable forward plan. As a relatively new prime minister with a self-confessed lack of deep interest in international affairs, Julia Gillard was not well placed to drive a white paper's development. Gillard also had an internal problem, which was to create a policy position able to distinguish her own leadership from that of Rudd. This Gillard did with her department's Australia in the Asian Century White Paper in October 2012 - an economically focused and overly optimistic

37 Commonwealth of Australia, Defending Australia (2009), p. 11

38 Bob Carr, Diary of a Foreign Minister (Sydney: New South Publishing, 2014), p. 395.

39 Commonwealth of Australia, Defence White Paper 2013 (Canberra: Department of Defence, 2013). 
assessment of the long-term prospects for growth in Asia. ${ }^{40}$ In some respects, this White Paper was developed using a similar approach to the 'Dibb model'. Ken Henry, an external expert and former Secretary of the Treasury, was brought in to develop the strategy. But Henry's report was not intended to present personal advice to government. The document received Cabinet endorsement as a complete statement of policy. Thus Gillard denied herself the opportunity to shape a more targeted policy after absorbing community reactions to the study.

The tide of Australian domestic politics in 2013 did not leave much time for a careful consideration of the more pessimistic assessment of regional security contained in Defence White Paper 2013 when contrasted with the considerably more benign assessments of the Asian Century White Paper and Gillard's January 2013 National Security Statement. ${ }^{41}$ The same force structure was presented as the outcome of the different strategic analytical work that took place in 2009 and 2013, which pointed to a breakdown in strategic policy rigour and indicated the breadth of the conceptual gaps between the various policy statements on offer. ${ }^{42}$ The 2013 Defence White Paper did, however, present a more nuanced assessment of regional security, including a more balanced assessment of China's role in the region and making the case for reinvigorated defence relationships with Indonesia, Papua New Guinea and Japan. The White Paper's lasting contribution to strategic thinking was to point to an important trend: 'a new Indo-Pacific strategic arc is beginning to emerge, connecting the Indian and Pacific Oceans through Southeast Asia.' That assertion helped to shape a stronger emphasis on defence posture in the White Paper, in addition to reiterating the capability development plan of 2009 and adding the acquisition of the 'Growler' electronic warfare equipped Super Hornet aircraft.

40 Commonwealth of Australia, Australia and the Asian Century White Paper (Canberra: Department of Prime Minister and Cabinet, Oct. 2012). With the change of government in October 2013, the Asian Century White Paper was quickly removed from the Department of Foreign Affairs and Trade's website, but it is helpfully still on the Defence website.

41 See a brief review of that statement here: Peter Jennings, 'National Security: The Decade after the Decade Before', ASPI: Strategist, 25 Jan. 2013, available at www.aspistrategist.org.au/ national-security-the-decade-after-the-decade-before.

42 I review these policy statements in more detail in Peter Jennings, 'Ken Henry's Asian Century', ASPI: Policy Analysis, No. 104 (Aug. 2012). See also Peter Jennings, 'Defence Challenges after the 2013 White Paper', Policy, Vol. 29, No. 2 (Winter 2013). 
Dibb's assessment of the 2009 and 2013 white papers is worth noting to assess the policy changes that had developed since 1986. On strategic geography, Dibb welcomed the emphasis the 2013 White Paper put on Australia's wider region as being the key likely priority for operations: 'the security of Southeast Asia as increasingly central to our own security':

That means the ADF's primary operational area must encompass the eastern Indian Ocean, the waters of Southeast Asia (including the South China Sea), the South Pacific and the Southern Ocean. This amounts to more than 10 per cent of the earth's surface and poses a substantial challenge to a defence force of less than 60,000 .

On force-structure priorities Dibb was less forgiving:

When it comes to force structure priorities and the defence budget this white paper is on weaker ground. If we are no longer structuring the defence force to fight a major power in high-intensity combat why do we still need 12 large submarines? This was an idea spawned by prime minister Rudd's advisers without rigorous strategic analysis. ${ }^{43}$

Although there is widespread agreement that submarines are an increasingly important capability for Australia, no clear justification was presented in the 2009 or 2013 statements as to why 12 rather than, say, nine or 15 submarines, was the nominated target. After the 2009 policy announcement, explanations for the number of submarines were offered based on assessments of what was needed to keep one or two boats continuously on patrol while others underwent maintenance

43 Paul Dibb, 'Show us the Money for Defence Spending', Australian, 6 May 2013. 
and preparation..$^{44}$ As soon as the number of 12 was released it was captured by an aggressive industry lobby in South Australia, which has politically made it very difficult for successive governments to change the policy setting.

Dibb described any implication from the 2009 White Paper that the submarine expansion was designed to impose substantial costs against a major power adversary (that is, China) as a 'dangerous indulgence', but stressed the importance of the capability in Australia's nearer region and South-East Asia. ${ }^{45}$ His assessment (writing with Richard Brabin-Smith) was that:

the policy focus on the defence of Australia and operations in our immediate region continues to be inviolable, especially with the expected continued growth of the economies and military potential of the major and middle powers of the Indo-Pacific. We have re-emphasised the centrality of a strategy that is maritime in focus. ${ }^{46}$

\section{Looking to the Future}

The defence policy development process initiated by Beazley in 1985 and undertaken by Dibb in his 1986 Review of Australia's Defence Capabilities, followed by the 1987 Defence White Paper, became a model that subsequent governments followed, albeit with variations

44 When asked in 2012 about why 12 submarines had been identified in the 2009 White Paper, the following exchange took place in Senate Estimates Committee hearings:

Rear Adm. Moffitt: When it comes to the academic analysis of the weight of forces necessary to defend a nation the size of Australia with its geography and population and the available budget to do that, the number we acquire of anything probably has more to do with the threshold of pain than it does with the absolute need to do the task.

Senator JOHNSTON: Can you just explain that? I do not quite follow you. When you say 'the threshold of pain', you mean cost and time -

Rear Adm. Moffitt: How much are we prepared to spend? It is a process of trading off our ability to invest in defence against the need.

Senator JOHNSTON: Let us just be clear: the operational concept has yet to be finished and you are not sure where the number 12 comes from?

Rear Adm. Moffitt: I cannot talk to the number 12 except that it is in the white paper.

See Foreign Affairs, Defence and Trade Legislation Committee, Estimates-Defence Portfolio, Senate Hansard, 28 May 2012.

45 Paul Dibb \& Richard Brabin-Smith, 'Australian Defence: Challenges for the New Government', Security Challenges, Vol. 9, No. 4 (2013), pp. 45-64, p. 58.

46 Dibb \& Brabin-Smith, 'Australian Defence' (2013), pp. 62-63. 
to the theme. The most successful of the various white papers were, in this author's view, the 1987 and 2000 statements. In both cases the white papers had sponsors - Beazley and Howard - who actively shaped the content and then stayed long enough in their jobs to see significant parts of the policy implemented. Dibb in 1986 and White in 2000 provided solid intellectual content and consulted sufficiently with the wider Defence establishment to get enough buy-in to give the policy a chance to succeed.

Other white papers were less successful. The 1976 statement was more a product of Tange's intellect than the Fraser Government's. Core concepts were implemented and funding - apart from a brief increase after the 1979 Soviet invasion of Afghanistan — was not sustained. The 2009 White Paper articulated a strong new policy direction with a maritime emphasis and presented a coherent and rather pessimistic account of the regional security outlook. But the policy's implementation faltered because of the chaotic nature of the Rudd Government and the bloody leadership handover from Rudd to Gillard. Without its chief sponsor, the 2009 statement lacked an advocate and planned funding did not materialise.

Will the 'Dibb model' survive as a favoured way of making defence policy? The answer is unequivocally 'yes'. The Coalition Government under Tony Abbott has made substantial use of externally led review teams to assist the 2016 White Paper project - the Defence 'External Expert Panel' - and to engage in a root and branch review of Defence organisational structure - the so-called First Principles Review by David Peever and his colleagues. The approach has become a standard trope of policymaking. Oppositions call for reviews of this type to draw attention to flaws in the government's approach. Governments undertake Dibb-style reviews to show their engagement and commitment to good policy outcomes.

Beyond the theatre of policy, the reality is that if external policy reviews are done well, they will help to shape good-quality outcomes. If anything, a tendency shown by recent governments of different political stripes has been to draw more heavily on advice that comes from sources outside of the Australian Public Service. Governments do this because they are looking for agility and for the intelligent 
fusing of policy objectives and political benefit, which is at the core of successful government. In the future we will see more rather than fewer 'Dibb model' reviews.

Has Defence got better at setting the conceptual basis for force structuring? Again, the answer is broadly 'yes'. It's still the case that there are important issues over which the Services and civilians will disagree - a recent example being over the level of capability required for the Sea 5000 project to replace the ANZAC-class frigates. ${ }^{47}$ Dibb remained uncomfortable about the structure of the Army, agreeing with the Plan Beersheba to restructure the Army into three multi-role combat brigades, but not with the heavier elements of the Land 400 plan for Army vehicles. The biggest challenge for Army, Dibb and Brabin-Smith maintain, is to fully embrace the amphibious capabilities that are inherent in the new Canberra-class 'landing helicopter dock' ships. ${ }^{48}$ For all of these differences over capability priority, current civil-military relations in Defence do not remotely approach the dysfunctionality of 1984-85.

It may be that operational experience and constant pressure for better performance from governments has meant that Defence has improved its ability to collaborate on complex policymaking and, arguably, to agree to sensible approaches to joint-capability development. However, it is noteworthy that the organisation has yet to effectively articulate, as Dibb observed, 'in any rigorous, analytical way' the precise basis for an Army structured around three regular brigades, and Air Force with around 100 combat aircraft and a Navy with six (or 12) submarines and 12 surface combatants. Several reasons may help to explain this apparent analytical gap. First, force structures are slow to change and are grounded in strong historical experience demonstrating the effectiveness of key capabilities. Second, outside of the major wars of the last century, the ADF remains a small force that is focused on the challenges of maintaining the viability of key force elements. A Navy with fewer than a dozen surface combatants is surely at the brink of viability.

47 See Cameron Stewart, 'Rebuff for Navy on Super Warships', Australian, 9 May 2015.

48 Dibb \& Brabin-Smith, 'Australian Defence' (2013), pp. 60-61. 
Further, the politics of reducing any military capabilities is difficult. While there was certainly a case to argue that the Army might not replace the Leopard tank, Howard was unwilling to make that call regardless of the case some strategists advanced to let the capability go. Force structures are 'sticky' - governments and Defence organisations tend to emphasise platform replacement, even though this can be a less than rigorous approach to designing new capabilities. Thus far disruptive new technologies have not really threatened the core assumptions of the 'balanced force' approach, although defence applications of cyber capabilities may do so in the future.

A concluding thought on politics is needed. It is often claimed that 'politics' is the enemy of good defence policy development, but as this survey has shown, politics done well is a critical component of delivering high-quality policy outcomes. Dibb's experiences in 1986 as well as the white paper process of 2000 were lucky to hit some 'sweet spots', where experienced political leaders engaged thoughtfully in policy design and then stayed on long enough to guide implementation. By contrast, dysfunctional politics produces poor policy outcomes. For the 'Dibb model' of policy development to work, an intelligent and pragmatic partnership needs to be struck between politicians and their professional advisers. 
This text is taken from Geography, Power, Strategy and Defence Policy: Essays in Honour of Paul Dibb, edited by Desmond Ball and Sheryn Lee, published 2016 by ANU Press, The Australian National University,

Canberra, Australia. 